Persistent Oligarchs 



\section{P E R S I S T E N T \\ O L I G A R C H S}

Elites and Politics in

Chihuahua, Mexico

$1910-1940$

Mark Wasserman

D UKE U N IVERS IT Y PRES S

Durham and London 1993 
(C) 1993 Duke University Press

All rights reserved

Printed in the United States of America

on acid-free paper $\infty$

Designed by Cherie Holma Westmoreland

Typeset in Bembo by Yankee Typesetters, Inc.

Library of Congress Cataloging-in-Publication

Data appear on the last printed page

of this book. 
This book is dedicated with great love to two generations: to my mother and father, Deborah S. and Herbert B. Wasserman, and to my children, Aaron and Danielle 
